\title{
Fish assemblage structure of the Ipanema River, a small lotic environment partially protected by a Conservation Unit in southeastern Brazil
}

\author{
Oliveira, AK. ${ }^{a *}$, Apone, F. ${ }^{b}$ Birindelli, JLO. ${ }^{c}$ and Garavello, JC. ${ }^{d}$ \\ ${ }^{a}$ Departamento de Ciências Ambientais, Universidade Federal de São Carlos - UFSCar, \\ Rod. Washington Luís, Km 235, CP 676, CEP 13565-905, São Carlos, SP, Brazil \\ 'Laboratório de Ictiologia de Ribeirão Preto - LIRP, Departamento de Biologia, Faculdade de Filosofia, \\ Ciências e Letras de Ribeirão Preto - FFCLRP, Universidade de São Paulo - USP, \\ Av. Bandeirantes 3900, CEP 14040-901, Ribeirão Preto, SP, Brazil \\ 'Departamento de Biologia Animal e Vegetal, Universidade Estadual de Londrina - UEL, \\ CP 10.011, CEP 86057-970, Londrina, PR, Brazil \\ 'Laboratório de Ictiologia Sistemática, Departamento de Ecologia e Biologia Evolutiva, \\ Universidade Federal de São Carlos - UFSCar, CEP 13565-905, São Carlos, SP, Brazil \\ *e-mail: pako@ufscar.br \\ Received April 12, 2012 - Accepted June 15, 2012 - Distributed May 31, 2013
}

(With 4 figures)

\begin{abstract}
A study on the fish assemblage of the Ipanema River, a small affluent of the Tietê River basin in southeastern Brazil, was performed aiming to look for structural patterns of species diversity in small lowland lotic environments. Fish samplings were performed every two months from June 2003 to April 2004 at four sample sites located on the lower stretch of the river. Local assemblage showed to be species rich, with fifty-two species belonging to Characiformes (25 spp.), Siluriformes (19 spp.), Cyprinodontiformes (3 spp.), Gymnotiformes (2 spp.), Perciformes (2 spp.), and Synbranchiformes (1 sp.). Fish fauna was composed of small-sized species $(<200 \mathrm{~mm} \mathrm{SL})$ and by individuals of medium (up to $400 \mathrm{~mm} \mathrm{SL}$ ) to large (more than $400 \mathrm{~mm} \mathrm{SL}$ ) sized species. The Ipanema River, such as other small lotic transitional environments in the upper Paraná River drainage, is considered important for conservation of fish fauna because they cover available habitats for persistent populations of small-sized species and for non-persistent individuals or shoals of medium and large-sized fish species, which occupy other habitats along their life-history (e.g. floodplains, oxbow lakes, main channel of great rivers). The importance of the Ipanema River basin for fish fauna conservation is also reinforced by the fact that it is located in a highly impacted region of southeastern Brazil, near the São Paulo metropolitan area.
\end{abstract}

Keywords: community structure, body size, conservation, neotropical, streams, upper Paraná River.

\section{Estrutura da assembleia de peixes do Rio Ipanema, um pequeno ambiente lótico parcialmente protegido por uma Unidade de Conservação no Sudeste do Brasil}

\begin{abstract}
Resumo
Um estudo sobre a estrutura da assembleia de peixes do Rio Ipanema, um pequeno afluente da bacia do Rio Tietê, no Sudeste do Brasil, foi realizado com o objetivo de buscar padrões estruturais de diversidade de espécies em pequenos ambientes lóticos de planícies. Peixes foram coletados a cada dois meses, de junho de 2003 a abril de 2004, em quatro locais de amostragem situados no trecho inferior do rio. A assembleia de peixes se mostrou rica em espécies, com 52 espécies registradas, pertencentes a 40 gêneros, 19 famílias e às ordens Characiformes ( 25 spp.); Siluriformes (19 spp.); Cyprinodontiformes (3 spp.); Gymnotiformes (2 spp.); Perciformes (2 spp.), e Synbranchiformes (1 sp.). A fauna de peixes foi composta por espécies de pequeno porte $(<200 \mathrm{~mm} \mathrm{CP})$ e por indivíduos de espécies que atingem porte médio (até $400 \mathrm{~mm} \mathrm{CP}$ ) e grande (mais de $400 \mathrm{~mm} \mathrm{CP}$ ). O Rio Ipanema, assim como outros pequenos ambientes lóticos de transição entre riachos e grandes rios na drenagem do Alto Rio Paraná, são considerados importantes para a conservação da ictiofauna porque representam habitats disponíveis para populações persistentes de espécies de pequeno porte e para indivíduos ou cardumes não persistentes de espécies de médio e grande porte, que podem ocupar outros habitats (por exemplo, as lagoas marginais, as planícies de inundação e as calhas principais de grandes rios), durante o transcorrer de sua vida. Esta importância para conservação também é ressaltada porque a Bacia do Rio Ipanema é localizada em uma região intensamente impactada do Sudeste do Brasil, próxima à área metropolitana de São Paulo.
\end{abstract}

Palavras-chave: estrutura de comunidade, tamanho corpóreo, neotropical, riachos, Alto Rio Paraná. 


\section{Introduction}

Tropical freshwater areas are considered important for biodiversity conservation and are experiencing great decline in biodiversity relative to other terrestrial ecosystems (Dudgeon et al. 2006). This is especially true in southeastern Brazil, the most developed region of the country, which was originally covered by Cerrado and Atlantic Forest, two biodiversity hotspots (Myers et al., 2000). In this region, as a direct consequence of urban and agricultural occupation, both terrestrial and aquatic environments have been damaged and modified, so that the few survivors of the biodiversity are now restricted to rural areas and to scarce areas protected by law, such as Conservation Units and forest reserves.

The Ipanema River is tributary of the Tietê River basin and drains through a governmental area of biodiversity conservation, the Floresta Nacional de Ipanema, created in 1992 and nowadays maintained by the Instituto Chico Mendes de Conservação da Biodiversidade (ICMBio). According to Brazilian law for conservation units, the category Floresta Nacional (FLONA) represents an area of multiple uses, destined to biodiversity conservation, as well as scientific research, education, tourism and recreation. The FLONA Ipanema is located at a bicentennial farm (Fazenda Ipanema), with constructions of what was probably the first metallurgic factory created in Brazil in 1810. According to Marques (1980), exploration of ore in the region started in the XVI century. The Ipanema River is dammed in the FLONA area, forming the small Hedberg Reservoir, one of the oldest reservoirs of the country, from which water was used at that time to generate hydraulic energy and to cool the factory ovens. Nowadays, the factory area represents a preserved historical patrimony within the FLONA.

Ipanema region has a long, but discontinuous, history of zoological observations initiated by naturalist expeditions during the $19^{\text {th }}$ century. The zoologist Johann Baptist von Spix, the botanist Carl Friedrich Philipp von Martius and the zoologist Johann Natterer visited the area herein studied during the first half of XIX century and collected anthropological, zoological and botanical information. Spix and Martius travelled through Brazil along four years, and during two weeks in 1818 stayed in the Ipanema region performing their activities (Spix and Martius, 1981). Natterer explored Brazilian lands for 18 years collecting elements of the entire fauna and travelled to Ipanema River twice. First he stayed from February 1819 to July 1820, and later from September 1821 to October 1822 (Ihering, 1902; Vanzolini, 1993). Fish specimens collected by Natterer were sent to the Naturhistorisches Museum in Vienna, and were partially studied by Rudolf Kner, who described Prochilodus vimboides from Ypanema (= Ipanema) in 1859. Auguste de Saint-Hilaire and Georg Heinrich Langsdorff were also in Ipanema during their expeditions in the XIX century (Ihering, 1902; Vanzolini, 1996).

In this paper we present a survey on fish diversity performed in a $5^{\text {th }}$ order stretch of Ipanema River. Fish richness, species composition and body size were used for assemblage structure analysis. These attributes allow us to compare data with other fish surveys performed in similar environments of the upper Paraná River drainage, to infer on patterns and processes involved in fish dynamics in small tributaries and to discuss the role of well-preserved tributaries for fish biodiversity conservation in highly disturbed areas of the upper Paraná River drainage.

\section{Methods}

\subsection{Study area}

The Ipanema River is a tributary of the Sorocaba River, itself a left-bank tributary to the Tietê River, upper Paraná River drainage, São Paulo state. The Ipanema River headwaters are located at $840 \mathrm{~m}$ of altitude between Sorocaba and Salto de Pirapora municipalities, and its mouth flows to the left margin of Sorocaba River at $605 \mathrm{~m}$ of altitude, at Iperó municipality. The area is situated in a transitional zone where Seasonal Semideciduous Forest predominates, but the occurrence of Dense and Mixed Broad-Leaf Forest (Atlantic Forest) and Savannah Forest (Cerrado) elements are also observed (Albuquerque and Rodrigues, 2000). Climate, according to the climatic classification of Koeppen, is Cwa, with dry winter and wet summer seasons. During the studied year the wet period (November to February) presented an accumulated rainfall of approximately $800 \mathrm{~mm}$, representing about $80 \%$ of the total rainfall in the studied year (approximately $1005 \mathrm{~mm}$ ), according to data provided by the Sorocaba climatological station.

\subsection{Fish sampling and data analysis}

Four sites located in a $5^{\text {th }}$ order stretch at the lower Ipanema River were sampled (Figure 1). The first one is located inside the FLONA and the three others are located downstream, outside this conservation area. The bank vegetation is relatively well preserved, composed of bushes and trees on both margins throughout the study sites. Each site is a $200 \mathrm{~m}$ long stretch of the river at approximately $620 \mathrm{~m}$ of altitude. Site 1 is shallow in its first half, with high water velocity and rocky bottom, and its last half presents pools with sand and clay bottom. Site 2 is predominantly a raceway stretch with sand-clay bottom, presenting some pools with fallen vegetable litter. Site 3 presents raceways with sand-gravel bottom intercalated by pools with sand-clay and fallen vegetable litter. Site 4 is a stretch with sand bottom and fallen wood-trunk raceway intercalated by sand-clay pools. Environmental features of all sites are presented in Table 1.

Fish samples were taken every two months, from June 2003 to April 2004, in the four sites. Fish were captured with a cast net (12 mm mesh), a small seine net ( $3 \mathrm{~mm}$ mesh), gill nets (from 15 to $35 \mathrm{~mm}$ mesh) and sieves ( $5 \mathrm{~mm}$ mesh). Fishery was actively performed (cast and seine nets and sieves) in all extension of each sample site for 2 hours, and gill nets (passive fishery) were used through 12 hours at night in deeper pools with slow water. 


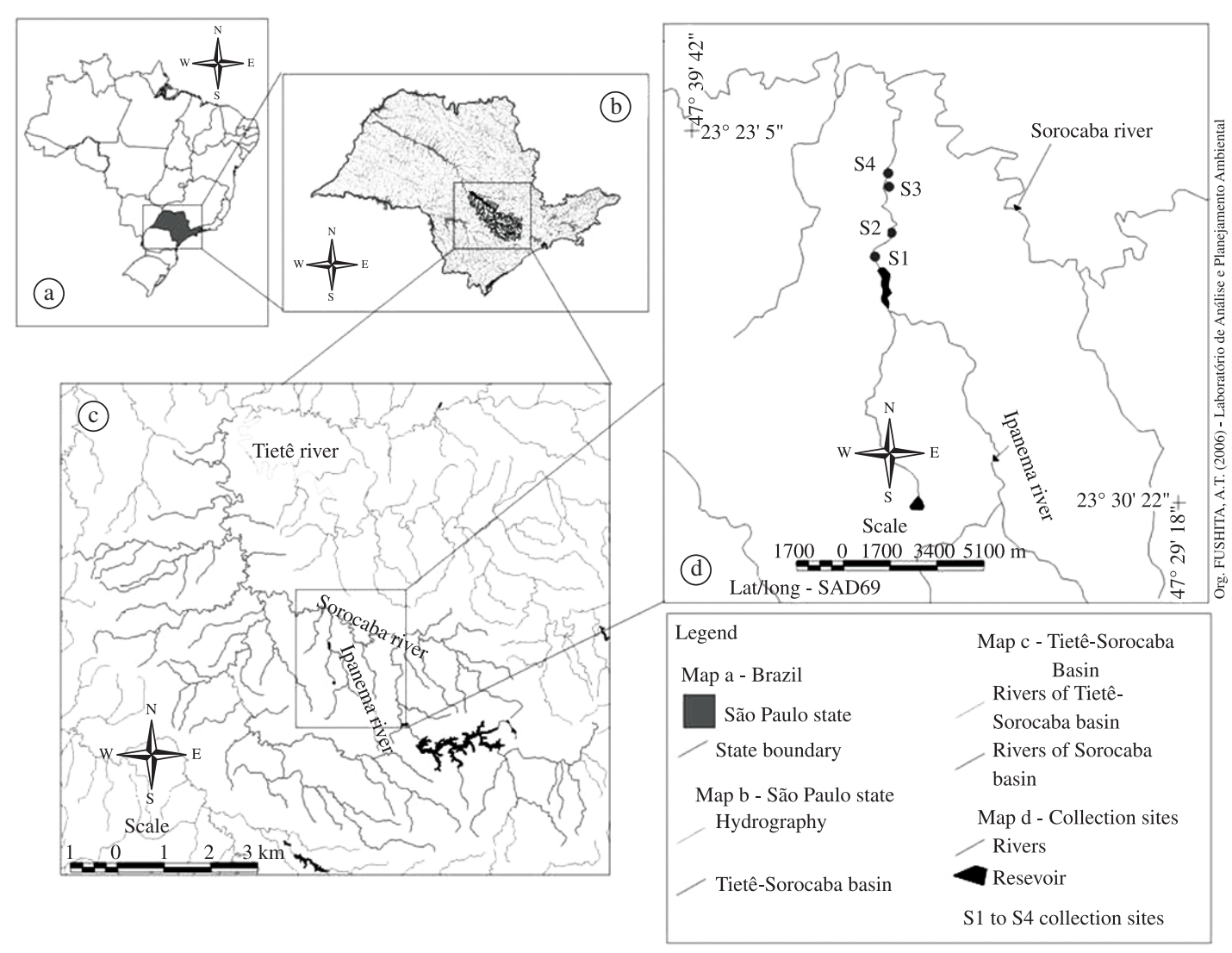

Figure 1. Map showing sampling site (dots) and the insertion of Ipanema River within the Sorocaba River and Tietê River basins, upper Paraná River drainage, southeastern Brazil.

Table 1. Environmental features of fish sample sites in Ipanema River, southeastern Brazil.

\begin{tabular}{|c|c|c|c|c|}
\hline & Site 1 & Site 2 & Site 3 & Site 4 \\
\hline Location & $\begin{array}{l}23^{\circ} 25,33 \text { ' S; } \\
47^{\circ} 35,47^{\prime}, \mathrm{W}\end{array}$ & $\begin{array}{l}23^{\circ} 25,05, ' \mathrm{~S} ; \\
47^{\circ} 35,26, \mathrm{~W}\end{array}$ & $\begin{array}{l}23^{\circ} 24 ' 11 ”, \mathrm{~S} ; \\
47^{\circ} 35,29 ” \mathrm{~W}\end{array}$ & $\begin{array}{l}23^{\circ} 23,55^{\prime \prime} \mathrm{S} \text {; } \\
47^{\circ} 35,30^{\prime \prime} \mathrm{W}\end{array}$ \\
\hline Maximum width & $10 \mathrm{~m}$ & $12 \mathrm{~m}$ & $16 \mathrm{~m}$ & $9 \mathrm{~m}$ \\
\hline $\begin{array}{c}\text { Depth } \\
\text { Mesohabitats }\end{array}$ & $\begin{array}{l}0.15 \text { to } 1.5 \mathrm{~m} \\
\text { run/riffle }\end{array}$ & $\begin{array}{c}0.2 \text { to } 1.5 \mathrm{~m} \\
\mathrm{run} / \mathrm{pool}\end{array}$ & $\begin{array}{c}0.2 \text { to } 1.7 \mathrm{~m} \\
\text { run/pool }\end{array}$ & $\begin{array}{c}0.3 \text { to } 2.0 \mathrm{~m} \\
\text { run/pool }\end{array}$ \\
\hline $\begin{array}{c}\text { Bank vegetation } \\
\text { Bottom type }\end{array}$ & $\begin{array}{c}\text { bushes/trees/grasses } \\
\text { rock/gravel/sand }\end{array}$ & $\begin{array}{c}\text { bushes/trees/grasses } \\
\text { sand/mud }\end{array}$ & $\begin{array}{c}\text { bushes/trees/grasses } \\
\text { gravel/sand/mud }\end{array}$ & $\begin{array}{c}\text { bushes/trees/grasses } \\
\text { sand/mud }\end{array}$ \\
\hline
\end{tabular}

Specimens were immediately preserved in $10 \%$ formalin solution and in the laboratory, conserved in $70^{\circ} \mathrm{GL}$ ethanol. The specimens are deposited in the fish collection of the Laboratório de Ictiologia Sistemática (LISDEBE) of the Departamento de Ecologia e Biologia Evolutiva of the Universidade Federal de São Carlos and are numbered as follow: LISDEBE 345, 711, 712, 732-750, 758-767, 775, 778-851, 870, 871, 879-898, 900-1127, 1134, 1136-1138, $1140,1148-1156,1523-1525$. Fish species were identified using comparative material deposited in LISDEBE and specific systematic literature for each group. Taxonomical classification follows Reis et al. (2003).
Species accumulation curve based on twenty samples represented by five collections (Aug, Oct, Dec, Feb, Apr) at each site was constructed to evaluate sampling effort. Data obtained in June 2003 are absent in this analysis because it was a pilot sample and fishes from each of the four sites were gathered in a single recipient in the field. We assumed that the approximation to an asymptotic curve indicates a good sample of fish assemblage composition. Also, Incidence-Based Coverage Estimator (ICE) was applied to estimate species richness. The software Estimate ${ }^{\odot} 5.0$ (Colwell, 1997) was used to randomise the sample order 
a hundred times to eliminate distortions in function of sample, creating a smooth curve, and to calculate ICE value.

The frequency distribution of the number of sampled months in which a species was present was informative about persistence of the species at the lower portion of Ipanema River (Winemiller, 1996). Literature information and personal observations on ecological characteristics and functional design of the inventoried species also contributed to the examination of the assemblage structure.

Standard lengths (SL) of all specimens were measured, except for those specimens belonging to the orders Gymnotiformes and Synbranchiformes, from which total length (TL) were obtained. Mean, standard deviation and minimum and maximum length for all species were registered to study body size structure of the fish assemblage. Normal probability plot was produced to represent the species' maximum body size distribution. The ShapiroWilk test for goodness-of-fit was applied, testing if species' maximum size distribution deviated from normality (Zar, 1999). Skewness was evaluated with one sample t-test (Sokal and Rholf, 1995).

\section{Results}

Fish composition comprised 52 species distributed in 40 genera, 19 families and 6 orders (Table 2). Characiformes (25 spp.) and Siluriformes (19 spp.) were the most species-rich orders, followed by Cyprinodontiformes (3 spp.), Gymnotiformes (2 spp.), Perciformes (2 spp.) and Synbranchiformes (1 sp.). The families Characidae (13 spp.) and Loricariidae (7 spp.) represented $40 \%$ of the species richness, followed by Anostomidae and Heptapteridae (4 spp. each); Callichthyidae and Poeciliidae (3 spp. each); Curimatidae, Parodontidae, Pseudopimelodidae and Cichlidae (2 spp.); Erythrinidae, Acestrorhynchidae, Crenuchidae, Prochilodontidae, Auchenipteridae, Aspredinidae, Trichomycteridae, Sternopygidae, Gymnotidae and Synbranchidae (only $1 \mathrm{sp}$.). The accumulation curve suggests that more species could be registered with increasing collect effort (Figure 2). Nevertheless its conformation indicates that the number of species would not be much greater than the registered one, and ICE estimated 59 species.

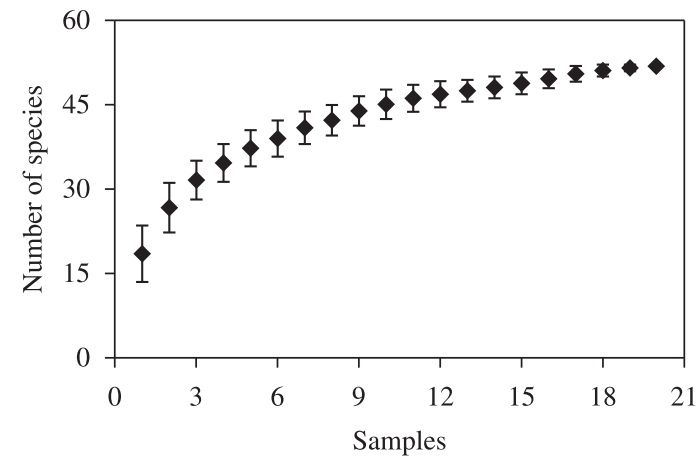

Figure 2. Accumulation curve of the number of fish species registered against number of samples in the lower stretch of the Ipanema River.
Frequency distribution of the number of sampled months in which a species was present showed to be bimodal with about $60 \%$ (31 spp.) of species present in four or more collection months and $40 \%$ in three collection months or less (Figure 3). The majority of these 31 species that occurred in four months or more must be considered as persistent in the lower stretch of the Ipanema River, but some of them may be transient and explore this environment just for a period of their life-histories, as do some known migratory species. In the same way, some species that occurred in three or less samples are probably persistent in the Ipanema River (see discussion below).

Maximum species body size distribution deviated from normality (Figure 4) and was significantly rightskewed $(\mathrm{n}=52, \mathrm{~W}=0.899, \mathrm{P}<0.05$; skew $=0.879$, $\left.\mathrm{SE}=0.330, \mathrm{t}_{\mathrm{s}=} 2.66, \mathrm{P}<0.05\right)$. The mean of species body size was $85.1 \mathrm{~mm}$, with the majority of species (approximately 69\%) presenting mean values lower than $100 \mathrm{~mm}$ of standard length, and $31 \%$ longer than this length, evidencing the predominance of small sized fish species in the assemblage composition (see Table 2). These include small-sized Characidae species of genus Astyanax, Bryconamericus, Hemigrammus, Hyphessobrycon, Piabina and Planaltina; the Cheirodontinae species; the

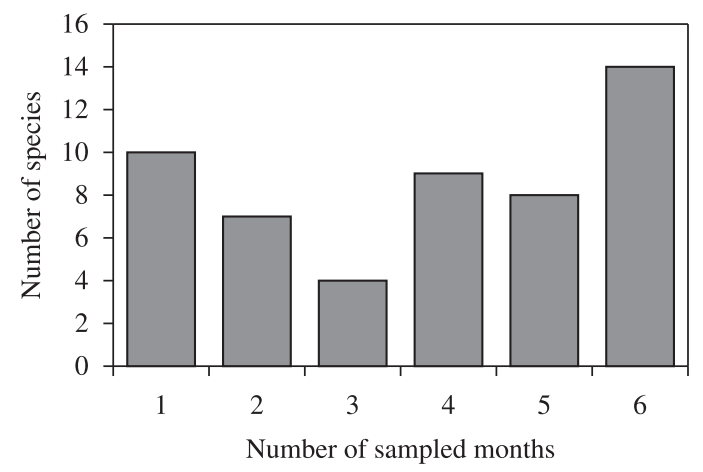

Figure 3. Frequency distribution of the number of sampled months in which individual fish species were present.

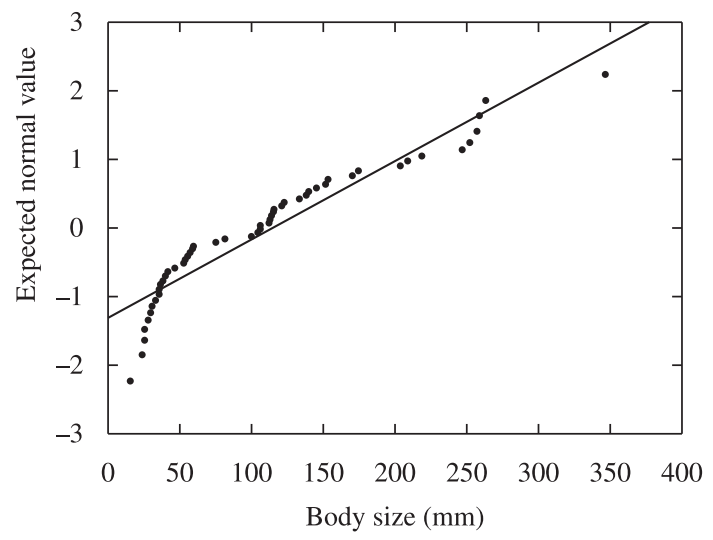

Figure 4. Normal probability plot of species maximum body size registered in lower Ipanema River between June 2003 and April 2004. 
Fish assemblage in a small Neotropical lotic environment

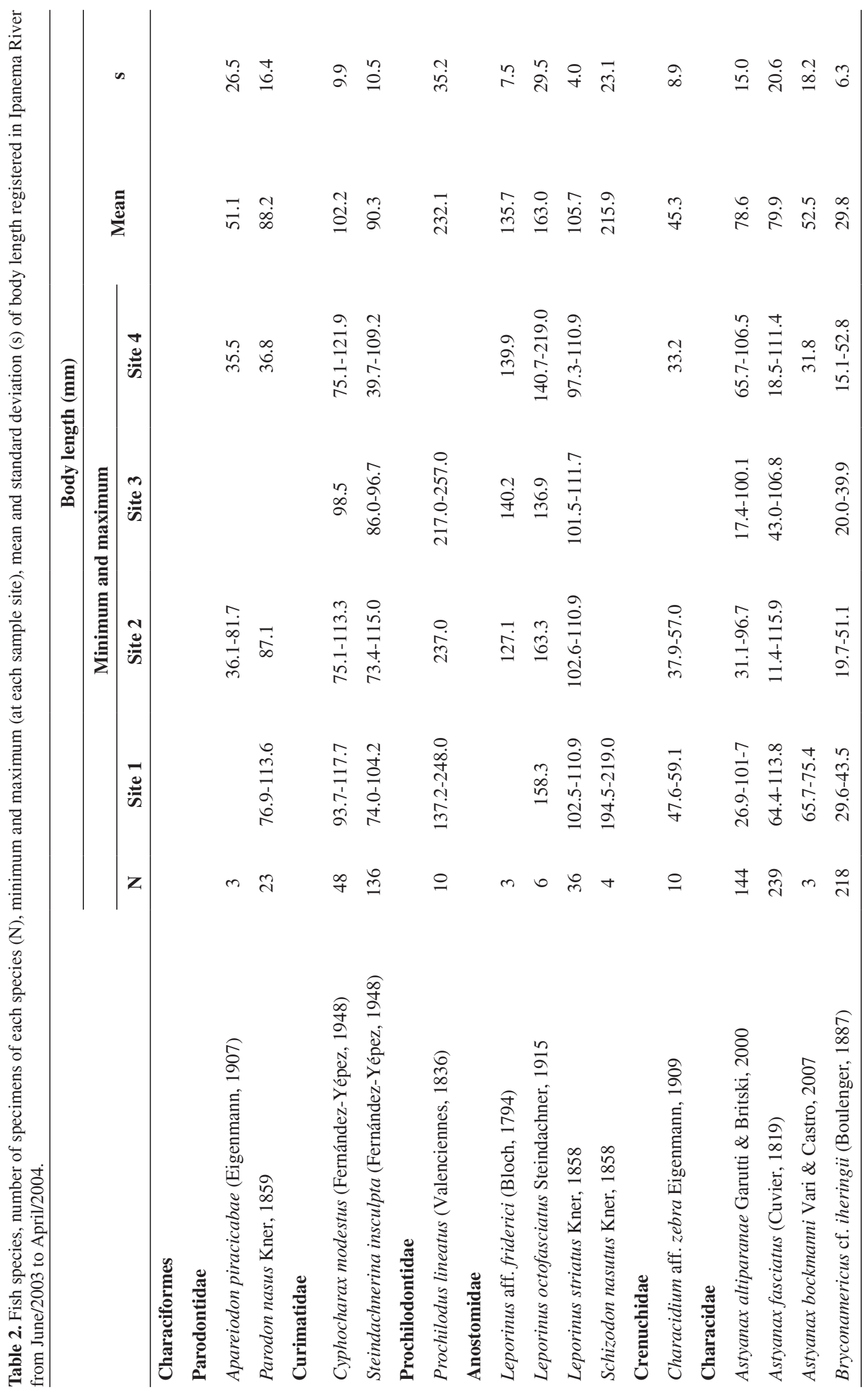




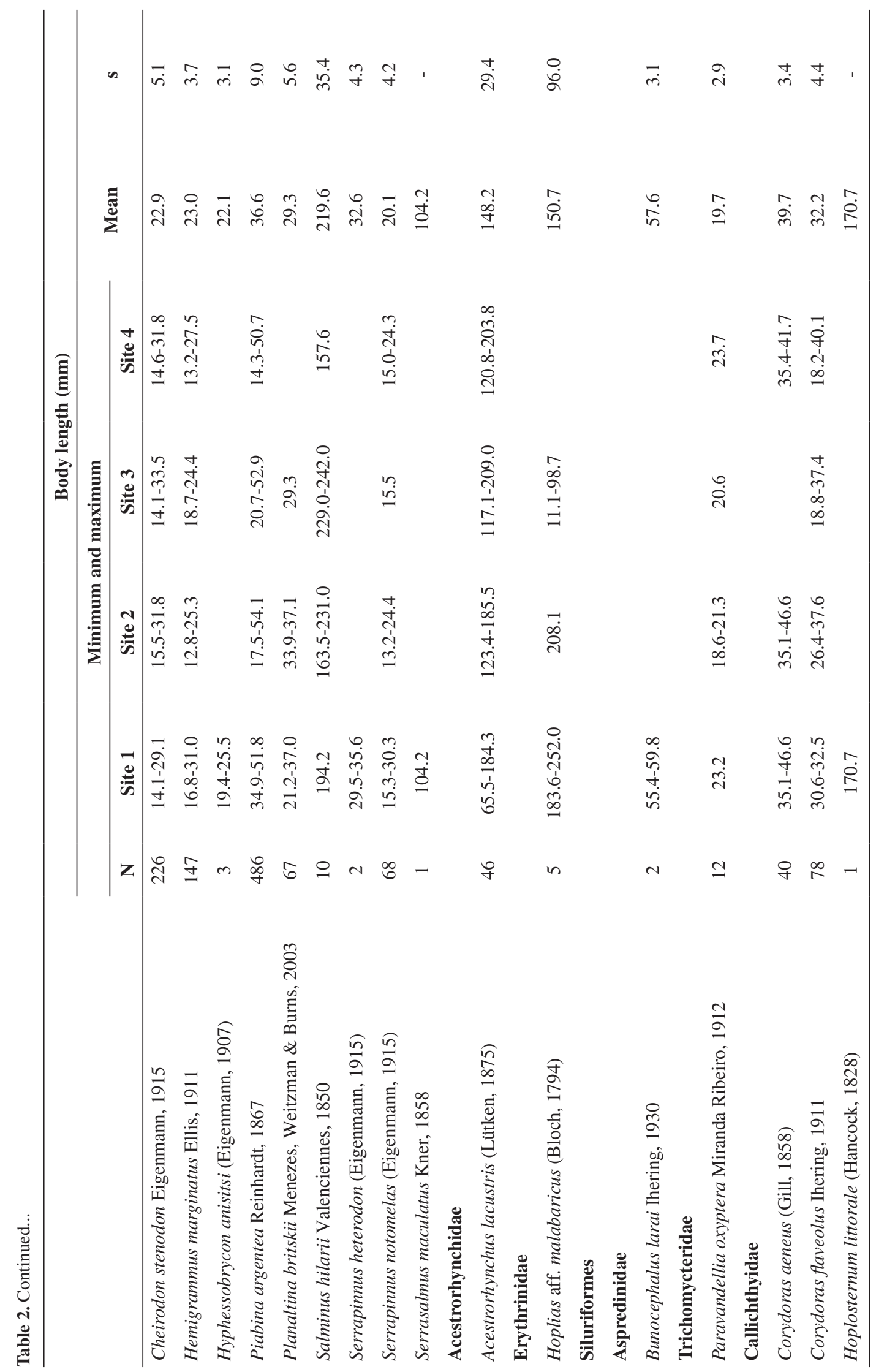




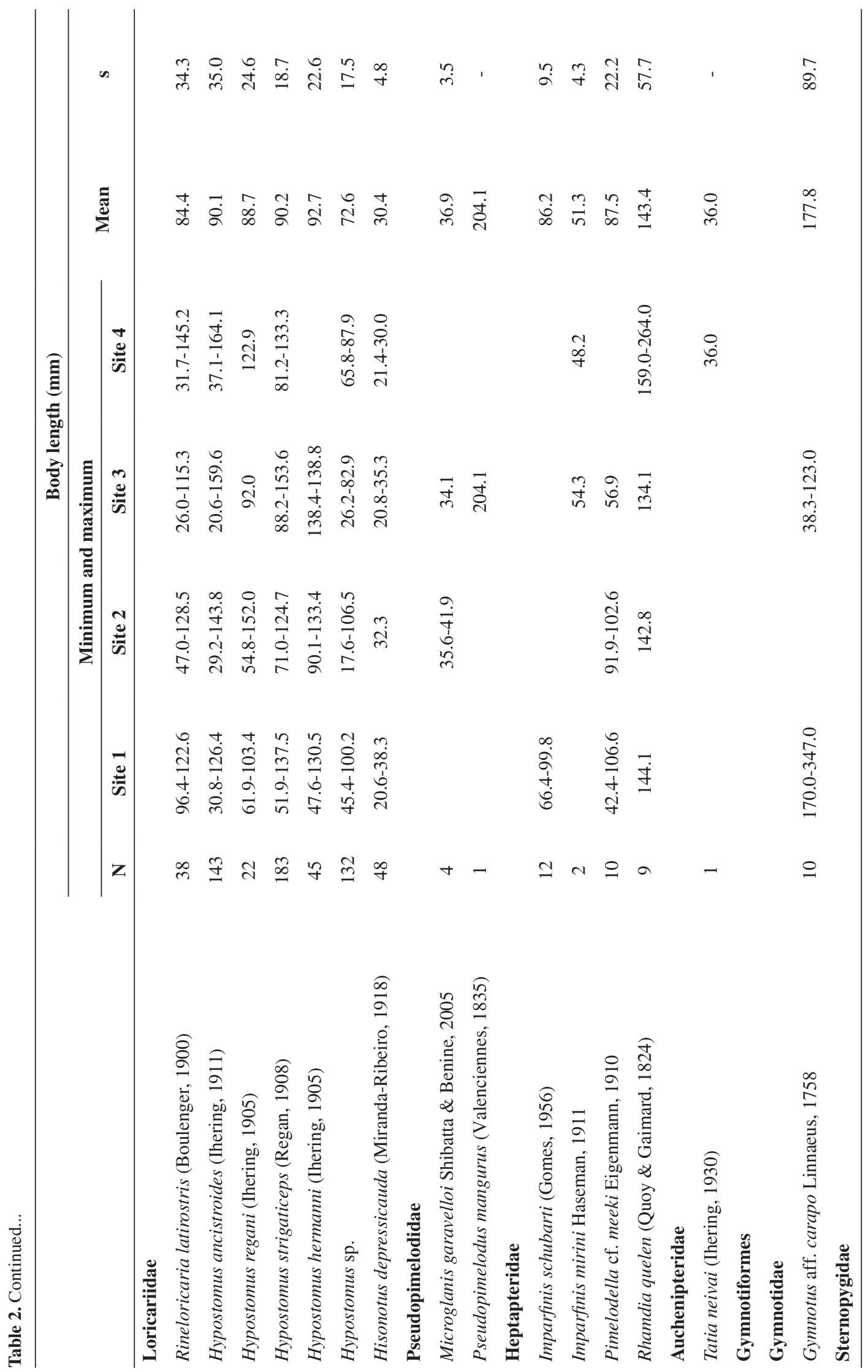


Oliveira, AK. et al.

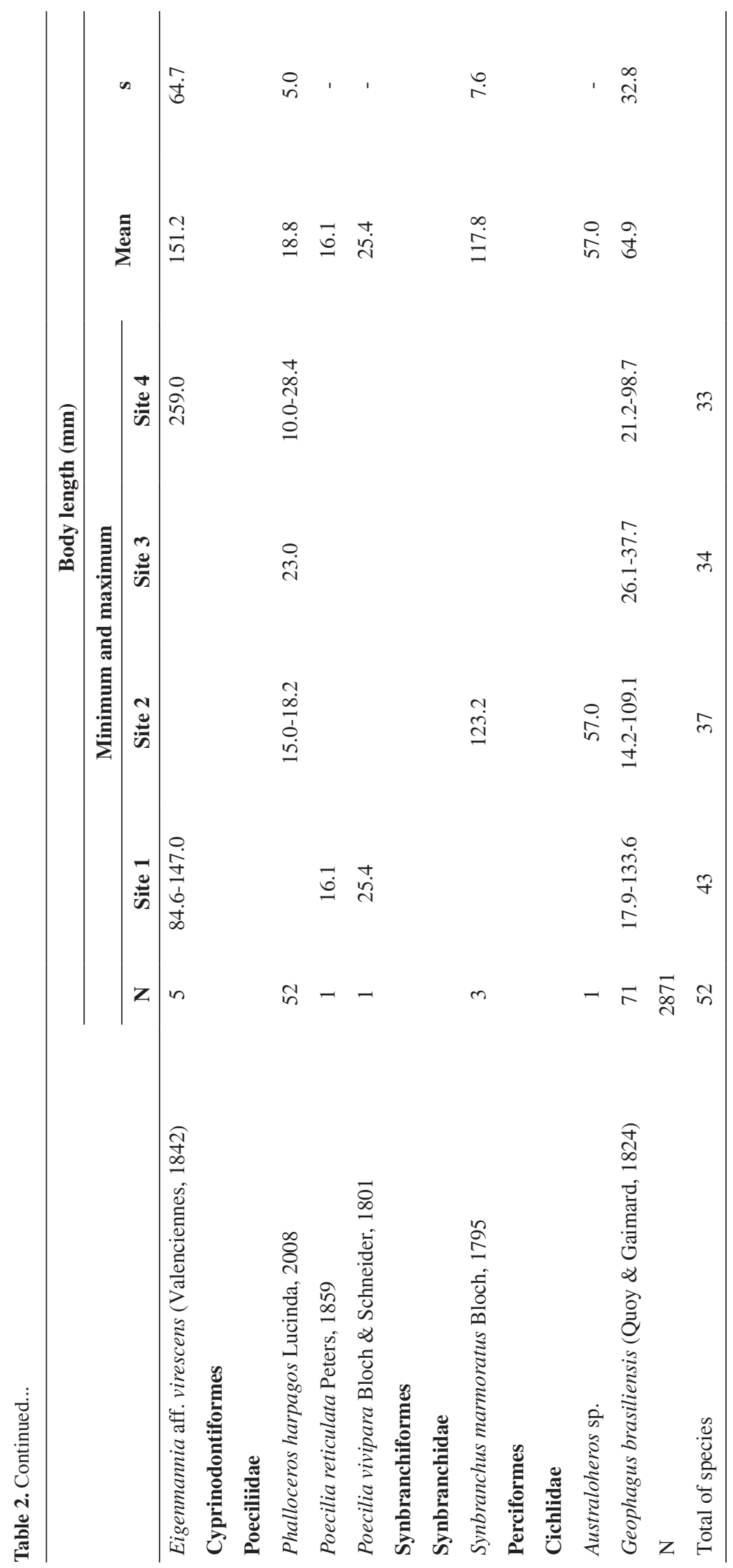


Crenuchidae Characidium aff. zebra; the Aspredinidae Bunocephalus larai; the Trichomycteridae Paravandellia oxyptera, the Callichthyidae of the genus Corydoras, the Heptapteridae species; the Auchenipteridae Tatia neivai; the Pseudopimelodidae Microglanis garavelloi, the Loricariidae Hisonotus depressicauda, the Poeciliidae species and the Cichlidae Australoheros sp.. Regarding the largest sized species registered, some are known to be migratory species, such as the Characidae Salminus hilarii; the Anostomidae Leporinus aff. friderici, L. octofasciatus, Schizodon nasutus and the Prochilodontidae Prochilodus lineatus. Others have relatively sedentary habits, preferentially inhabiting submersed vegetation and roots of bank vegetation, as the Gymnotiformes Gymnotus aff. carapo and Eigenmannia aff. virescens and the Erythrinidae Hoplias malabaricus, or live in hiding-places in the bottom and banks, as Synbranchus marmoratus and are also members of the persistent fauna.

\section{Discussion}

In a recent overview on ichthyofaunistic composition in the upper Paraná River drainage Langeani et al. (2007) listed 321 fish species, including native and introduced forms. As the authors predicted, this number of species has already increased in function of more collecting effort, species description and taxonomical revision of diverse fish groups, reaching nowadays about 350 fish species. Therefore, the number of species registered in the lower stretch of Ipanema River represents about $15 \%$ of the entire fish richness actually encountered in the great upper Paraná drainage.

Species richness estimated (ICE estimator) in the lower Ipanema River may be considered plausible. With greater collection effort, more non-persistent species would probably be registered due to the proximity of the studied sites with the Sorocaba River main channel. In fact, small rivers in the upper Paraná basin seasonally receives an amount of fishes from adjacent areas, chiefly from downstream great river channels, that in rainy periods temporarily perform their biological activities in expanded water environments. Also, the occurrence of some persistent species not registered in our study period in function of low individuals density or life strategies that hamper their capture would increase the number of species here registered.

Fish richness and composition in the Ipanema River is comparable to other relatively similar environments in the upper Paraná River drainage. Studies performed in $4^{\text {th }}$ and $5^{\text {th }}$ order stretches of rivers in this drainage evidence that Ipanema River presents a rich and representative ichthyofauna that potentially occupy this kind of environment. Pavanelli and Caramaschi (1997) recorded 71 species in two streams flowing directly to Rio Paraná main channel; Oliveira et al. (2009) recorded from 38 to 51 species in the lower portions of four small tributaries of the Mogi Guaçu River and Langeani et al. (2005) recorded 33 fish species in a $5^{\text {th }}$ order tributary of Tietê River. Concerning the fish community of Sorocaba River, Smith et al. (2009) reported 38 fish species in a variety of environments that include streams, small rivers, main river channel, marginal lagoons and reservoirs of this basin. Marciano et al. (2004) registered 34 fish species in seven tributaries with $2^{\text {nd }}$ to $4^{\text {th }}$ orders from the Sorocaba River basin, including the Ipanema River, where they collected thirteen species in each one of the seasonal sampled periods.

Small transitional places as defined herein, i. e. these lotic environments between headwaters $\left(1^{\text {st }}\right.$ to $3^{\text {rd }}$ stream orders) and medium to large river channels (more than $5^{\text {th }}$ order), are still to be better studied in the Neotropical region. The scarcity of long term studies in the river basins does not allow a satisfactory understanding about fish movements, occupation and exploration in these transitional habitats. Fish surveys performed in small tributaries of the Paraná River (Penczak et al., 1994; Pavanelli and Caramaschi, 1997), of Mogi Guaçu River (Oliveira and Garavello, 2003; Birindelli and Garavello, 2005; Perez-Junior and Garavello, 2007; Apone et al., 2008) and of Tietê River (Langeani et al., 2005), all inserted in the upper Paraná River drainage, showed that fish fauna are composed of many persistent and other non-persistent species that explore these environments for reproduction, growth and feeding activities. Fish populations of small body size (up to $200 \mathrm{~mm} \mathrm{SL}$ ) characterise the former group of species, and individuals of medium to large sized species (more than $200 \mathrm{~mm}$ SL) compose the latter. These studies also suggest that $4^{\text {th }}$ and $5^{\text {th }}$ order stretches of streams are species rich places and may contribute substantially to the maintenance of fish diversity at upper Paraná River drainage as a whole. Fish richness and the persistence of the large sized species may be conditioned by water volume, proximity of the stream stretches with the main great river channel, with seasonal flood cycle and with the declivity of such small rivers. This last factor was shown to be important for reproductive migratory fish movement in the tributary of Mogi Guaçu River studied by Oliveira and Garavello (2003). Young of great sized species may persist in small rivers stretches for more than a hydrological cycle but, as they grow, habitats with high water volume become necessary for occupation and exercise of their biological activities.

In a long term study in small freshwater environments in the Venezuela Llanos, Winemiller (1996) reported and discussed the fish assemblage dynamics identifying groups of persistent and non-persistent species. His results show that diverse fish species make use of their morphological and physiological characteristics to explore the changeable environmental conditions improved by high and low water seasonal periods. In the Ipanema River, we promptly identified some persistent species based on their frequency in sampled months and known distribution in small rivers; but we also discuss the persistence or non-persistence of species based on their biological attributes.

Among the Characiformes species immediately recognised as persistent are: Hoplias aff. malabaricus; Acestrorhynchus lacustris; small characids, as Astyanax altiparanae, Astyanax fasciatus, Bryconamericus cf. iheringii, Cheirodon stenodon, Hemigrammus marginatus, Piabina 
argentea, Planaltina britskii and Serrapinnus notomelas; Parodon nasus; Steindachnerina insculpta and Cyphocharax modestus; and Leporinus striatus. Prochilodus lineatus occurred in four sampled months but is here considered a non-persistent species because of its known migratory reproductive behaviour in large rivers of the upper Paraná drainage. In fact, this species reaches $700.0 \mathrm{~mm}$ of standard length and in the Ipanema River only individuals up to $257.0 \mathrm{~mm}$ were recorded. Persistent species of the order Siluriformes include Rineloricaria latirostris, Hisonotus depressicauda, Hypostomus ancistroides, H. hermanni, H. regani, H. strigaticeps, Hypostomus sp., Corydoras aeneus, C. flaveolus, Paravandellia oxyptera, Imparfinis schubarti and Rhamdia quelen. The gymnotiforms Eigenmannia aff. virescens and Gymnotus aff. carapo, the cyprinodontiform Phalloceros harpagos and the cichlid Geophagus brasiliensis must also be considered persistent species.

Some species that occurred in less than four collection months are non-persistent, such as Leporinus aff. friderici, L. octofasciatus, Schizodon nasutus and Salminus hilarii, which are usually registered in large river channels and reservoirs, and that perform reproductive migrations in tributaries of upper Paraná drainage. Some small-sized species of the order Characiformes, such as Astyanax bockmanni, Characidium aff. zebra and Apareiodon piracicabae, and of the Siluriformes, such as Microglanis garavelloi, Imparfinis mirini, Pimelodella cf. meeki and the Synbranchiformes Synbranchus marmoratus occurred only in two or three months but may be considered persistent in the Ipanema River since they are species commonly encountered in environments with low water volume, such as creeks and streams of the upper Paraná River drainage. Ten species occurred in a single month: Hyphessobrycon anisitsi, Serrapinnus heterodon, Serrasalmus maculatus, Pseudopimelodus mangurus, Hoplosternum littorale, Tatia neivai, Bunocephalus larai, Poecilia reticulata, Poecilia vivipara and Australoheros sp. Of them, S. maculatus and P. mangurus are common to large rivers and may be considered non persistent in the Ipanema River, the others have high incidence in stream habitats and their rarity may be a consequence of small population size and life habits, which hamper their capture, and should also be considered as persistent species.

The body size structure of the Ipanema River reveals a fish assemblage with predominance of small-sized fish species and presence of individuals of medium to large sized species. This was evidenced with the frequency distribution of the maximum species body size registered, which showed to be significantly right skewed, and by the species body size mean. Incidence of medium to large sized species was higher than observed in creeks and streams (1st to 3rd order stretches) already studied in the upper Paraná River drainage, which presented from 0.5 to $1 \%$ of individuals greater than $150 \mathrm{~mm}$ (Castro et al. 2003, 2004, 2005). In a study focussed on fish assemblage body size structure of streams in the Tibagi River basin, Shibatta and Cheida (2003) also reported predominance of small-sized species and the occurrence of young individuals of larger species, suggesting that streams are important places for early life stages of these species.

Animal body size can be considered a good descriptor of assemblage structure in any sort of environment. Kozłowski and Gawelczyk (2002) discussed patterns of body size distribution in animal assemblages showing that right skewed distribution is more common than normal or left skewed distributions, chiefly when great areas and high taxonomical levels are considered. Alternatively, local communities often show normal or left skewed distribution, which may be explained by the existence of landscape filters or the absence of some species in function of their specific traits. Here we hypothesised that transitional lotic environments of the upper Paraná River drainage, such as the lower stretch of Ipanema River studied herein, may show right skewed body size species distributions in the absence of physical barriers to fish movement (such as waterfalls or provided by anthropogenic activities) from downstream areas. Local assemblages in these environments are highly influenced by regional diversity and show a combination of small-sized persistent species and medium to great sized species that may or may not persist in these areas. So, in the area herein studied, these medium to great sized fishes tend to migrate from large rivers downstream, like Sorocaba River, which Ipanema River flows, or even from the Tietê River.

The number of species reported for the studied stretch, if compared with the ichthyofauna of Sorocaba River sampled in previous works (Marciano et al. 2004; Smith et al. 2009), shows this relatively very well-preserved area of the Ipanema River as highly contributive to local and regional species richness. Occurrence of relatively rare species in scientific fish collections such as Tatia neivai, Bunocephalus larai and Microglanis garavelloi also suggest that the Ipanema River is a precious river within the aquatic endangered environments of São Paulo state. The importance in preserving the Ipanema River basin is reinforced by the fact that B. larai, Pseudopimelodus mangurus and $P$. vimboides are classified as "vulnerable" in the threatened species list of species from São Paulo state (Oyakawa et al., 2009). In addition, Sorocaba basin is the type locality of some species from the upper Paraná River drainage, such as the loricariids Hypostomus ancistroides and Hisonotus depressicauda, both collected in Ipanema by us, and of the prochilodontid Prochilodus vimboides, not registered in our samples.

As stated by Casatti et al. (2009), reference areas are difficult to find in São Paulo state and this is mainly due to the fact that this is one of the most densely occupied and impacted regions in South America, chiefly near São Paulo municipality, where the Sorocaba River Basin is located. Also according to Dudgeon et al. (2006), it is important to recognize the potential that partially degraded habitats may have to support significant portions of their original biodiversity, while preservation of intact freshwater bodies and their biodiversity remains a priority. In highly impacted river basins of São Paulo state, fish fauna are stunted and 
any well-preserved aquatic environment would play a significant role for fish conservation and management.

The lower stretch of Ipanema River is one of much transitional environments between streams and large rivers of upper Paraná River drainage important to be preserved and which ecological function in the maintenance of the regional fish communities are still poorly studied and comprehended. Our results added by information of other fish studies performed in small rivers of this great fluvial system suggest that these environments exhibit richer fish fauna than headwaters creeks or small streams. Since the Ipanema River belongs to one of the most densely occupied urban regions in South America, and because it drains through an official area for biodiversity conservation (Flona Ipanema) and exhibits this rich fish fauna, we think its conservation may be facilitated and programmes with this objective must be applied. In this way, those propositions for fish recovery and conservation pointed out by Silva et al. (2006) and which included preservation of bank vegetation, control of urban effluents and monitoring of fish populations, may be intensified in small transitional lotic environments from the upper Paraná River drainage.

Acknowledgements - We thank Alexandre W. S. Hilsdorf, Alaíde A. F. Gessner, José R. Verani, Marcel O. Tanaka, Nelsy F. Verani and Tadeusz Penczak for criticism and suggestions. Fabio O. Roque and Tadeu Siqueira helped with the body size statistical analysis. Angela Fushita provided the map. The Instituto Brasileiro do Meio Ambiente e dos Recursos Naturais Renováveis (IBAMA) and the executive direction of FLONA Ipanema provided permission to collect fish in Ipanema River. Marinha do Brasil allowed fish collection in the area of the Centro Experimental Aramar (CEA), in Iperó. AKO received a grant from Capes (Coordenadoria de Aperfeiçoamento de Pessoal de Nível Superior) through the Programa de Pós Graduação em Ecologia e Recursos Naturais (PPG-ERN UFSCar), FA received a grant from $\mathrm{CNPq}$ (Conselho Nacional de Pesquisa Tecnológica do Brasil) through PIBIC, JLOB received a grant from FAPESP (Fundação de Amparo à Pesquisa do Estado de São Paulo), and JCG received a grant from CNPq (Conselho Nacional de Pesquisa e Tecnologia). This study received financial support from FAPESP (Process 2011/50213-5) in the BIOTA/FAPESP Program (www.biota.org.br).

\section{References}

ALBUQUERQUE, GB. and RODRIGUES, RR., 2000. A vegetação do Morro de Araçoiaba, Floresta Nacional de Ipanema, Iperó, SP. Scientia Florestalis, vol. 58, p. 145-159.

APONE, F., OLIVEIRA, AK. and GARAVELLO, JC., 2008. Composição da ictiofauna do rio Quilombo, tributário do rio Mogi-Guaçu, bacia do alto rio Paraná, sudeste do Brasil. Biota Neotropica, vol. 8, no. 1, p. 93-107. http://dx.doi.org/10.1590/ S1676-06032008000100012

BIRINDELLI, JLO. and GARAVELLO, JC., 2005. Composição, distribuição e sazonalidade da ictiofauna do ribeirão das Araras, bacia do alto rio Paraná, São Paulo, Brasil. Comunicações do Museu de Ciências e Tecnologia da PUCRS, série Zoologia, vol. 18 , no. 1, p. 37-51.

CASATTI, L., FERREIRA, CP. and LANGEANI, F., 2009. A fish-based biotic integrity index for assessment of lowland streams in southeastern Brazil. Hydrobiologia, vol. 623, p. 173-189. http:// dx.doi.org/10.1007/s10750-008-9656-x

CASTRO, RMC., CASATTI, L., SANTOS, HF., FERREIRA, KM., RIBEIRO, AC., BENINE, RC., DARDIS, GZP., MELO, ALA., STOPIGLIA, R., ABREU, TX., BOCKMANN, FA., CARVALHO, M., GIBRAN, FZ. and LIMA, FCT., 2003. Estrutura e composição da ictiofauna e riachos da bacia do rio Paranapanema, sudeste e sul do Brasil. Biota Neotropica, vol. 3, no. 1, p. 1-31.

CASTRO, RMC., CASATTI, L., SANTOS, HF., MELO, ALA., MARTINS, LSF., FERREIRA, KM., GIBRAN, FZ., BENINE, RC., CARVALHO, M., RIBEIRO, AC., ABREU, TX., BOCKMANN, FA., PELIÇÃO, GZ., STOPIGLIA, R. and LANGEANI, F., 2004. Estrutura e composição da ictiofauna e riachos da bacia do rio Grande no estado de São Paulo, sudeste do Brasil. Biota Neotropica, vol. 4 , no. 1, p. 1-39.

CASTRO, RMC., CASATTI, L., SANTOS, HF., VARI, RP., MELO, ALA., MARTINS, LSF., ABREU, TX., BENINE, RC., GIBRAN, FZ., RIBEIRO, AC., BOCKMANN, FA., CARVALHO, M., PELIÇÃO, GZ., FERREIRA, KM., STOPIGLIA, R. and AKAMA, A., 2005. Structure and composition of the stream ichthyofauna of four tributary rivers of the upper Rio Paraná basin, Brazil. Ichthyological Exploration of Freshwaters, vol. 16, no. 3, p. 193-214.

COLWELL, RK., 1997. EstimateS: Statistical estimation of species richness and shared species from samples. version 5. Available from: <http://viceroy.eeb.uconn.edu/estimates >

DUDGEON, D., ARTHINGTON, AH., GESSNER, MO., KAWABATA, Z., KNOWLER, DJ., LÉVÊQUE, C., NAIMAN, RJ., PRIEUR-RICHARD, A., SOTO, D., STIASSNY, MLJ. and SULLIVAN, CA., 2006. Freshwater biodiversity: importance, threats, status and conservation challenges. Biological reviews, vol. 81, no. 2, p. 163-182. PMid:16336747. http://dx.doi.org/10.1017/ S1464793105006950

IHERING, H., 1902. Natterer e Langsdorff: exploradores antigos do Estado de São Paulo. Revista do Museu Paulista, vol. 5, p. 13-34.

KOZŁOWSKI, J. and GAWELCZYK, AT., 2002. Why are species' body size distributions skewed to the right? Functional Ecology, vol. 16, p. 419-432. http://dx.doi.org/10.1046/j.13652435.2002.00646.x

LANGEANI, F., CASATTI, L., GAMEIRO, HS., CARMO, AB. and ROSSA-FERES, DC., 2005. Riffle and pool fish communities in a large stream of southeastern Brazil. Neotropical Ichthyology, vol. 3, no. 2, p. 305-311. http://dx.doi.org/10.1590/S167962252005000200009

LANGEANI, F., CASTRO, RMC., OYAKAWA, OT., SHIBATTA, OA., PAVANELLI, CS. and CASATTI, L., 2007. Diversidade da ictiofauna do Alto Rio Paraná: composição atual e perspectivas futuras. Biota Neotropica, vol. 7, no. 3, p. 181-197. http://dx.doi. org/10.1590/S1676-06032007000300020

MARCIANO, FT., CHAUDHRY, FH. and RIBEIRO, MCLB., 2004. Evaluation of the Index of Biotic Integrity in the Sorocaba River Basin (Brazil, SP) based on fish communities. Acta Limnologica Brasiliensia, vol. 16, no. 3, p. 225-237.

MARQUES, MEA., 1980. Apontamentos históricos, geográficos, biográficos, estatísticos e noticiosos da Província de São Paulo: seguidos da Cronologia dos acontecimentos mais notáveis desde a fundação da Capitania de São Vicente até o ano de 1876, vol. 1. Belo Horizonte: Ed. Itatiaia. 379 p. 
MYERS, N., MITTERMEIER, RA., MITTERMEIER, CG., FONSECA, GAB. and KENT, J., 2000. Biodiversity hotspots for conservation priorities. Nature, vol. 403, p. 853-858. PMid:10706275. http://dx.doi.org/10.1038/35002501

OLIVEIRA, AK. and GARAVELLO, JC., 2003. Fish assemblage composition in a tributary of the Mogi Guaçu River basin, Southeastern Brazil. Iheringia, Série Zoologia, vol. 93, no. 2, p. 127-138.

OLIVEIRA, AK., APONE, F., BIRINDELLI, JLO. and PEREZJUNIOR, OR., 2009. Fish, tributaries of middle Rio Mogi Guacu, upper rio Parana basin, Sao Paulo state, Southeastern Brazil. Check List, vol. 5, no. 3, p. 488-494.

OYAKAWA, OT., MENEZES, NA., SHIBATTA, OA., LIMA, FCT., LANGEANI, F., PAVANELLI, CS., NIELSEN, DTB. and HILSDORF, AWS., 2009. Peixes de água doce. In BRESSAN, PM., KIERULFF, MCM. and SUGIEDA, AM. (Orgs.). Fauna ameaçada de extinção no Estado de São Paulo. Vertebrados. São Paulo: Fundação Parque Zoológico de São Paulo: Secretaria do Meio Ambiente. vol. 1, p. 349-424.

PAVANELLI, CS. and CARAMASCHI, EP., 1997. Composition of the ichthyofauna of two small tributaries of the Paraná river, Porto Rico, Paraná State, Brazil. Ichthyological Exploration of Freshwaters, vol. 8, no. 1, p. 23-31.

PENCZAK, T., AGOSTINHO, AA. and OKADA, EK., 1994. Fish diversity and community structure in two small tributaries of the Paraná River, Paraná State, Brazil. Hydrobiologia vol. 294, no. 3, p. 243-251. http://dx.doi.org/10.1007/BF00021297

PEREZ-JÚNIOR, O. and GARAVELLO, JC., 2007. Ictiofauna do Ribeirão do Pântano, afluente do Rio Mogi-Guaçu, Bacia do Alto Rio Paraná, São Paulo, Brasil. Iheringia, Série Zoologia, vol. 97, no. 3, p. 328-335. http://dx.doi.org/10.1590/S007347212007000300018

REIS, RE., KULLANDER, SO. and FERRARIS, CJ., 2003. Check list of the freshwater fishes of South and Central America. Porto Alegre: EDIPUCRS. 742 p.
SHIBATTA, OA. and CHEIDA, CC., 2003. Composição em tamanho dos peixes (Actinopterygii, Teleostei) de ribeirões da bacia do rio Tibagi, Paraná, Brasil. Revista Brasileira de Zoologia, vol. 20, no. 3, p. 469-473. http://dx.doi.org/10.1590/ S0101-81752003000300016

SILVA, FSD., DEUS, JRM. and HILSDORF, AWS., 2006. The upper reached ichthyofauna of the Tietê River, São Paulo, Brazil: aspects of their diversity and conservation. Biodiversity and Conservation, vol. 15, p. 3569-3577. http://dx.doi.org/10.1007/ s10531-004-1460-y

SMITH, WS., PETRERE JUNIOR, M. and BARRELA, W., 2009. The fish community of the Sorocaba River Basin in different habitats (São Paulo State, Brazil). Brazilian Journal of Biology vol. 69, no. 4, p. 1015-1025. PMid:19967172. http://dx.doi. org/10.1590/S1519-69842009000500005

SOKAL, RR. and ROHLF, FJ., 1995. Biometry: the principles and practice of statistics in biological research. 3rd ed. New York: W.H. Freeman and Company. 887 p.

SPIX, JB. and MARTIUS, CFP., 1981. Viagem pelo Brasil: 1817-1820, vol. 1. Belo Horizonte: Ed. Itatiaia. São Paulo: Ed. Universidade de São Paulo. 262 p.

VANZOLINI, PE., 1993. As viagens de Johann Natterer no Brasil, 1817-1835. Papéis Avulsos de Zoologia, vol. 38, no. 3, p. $17-60$.

-, 1996. A contribuição zoológica dos primeiros naturalistas viajantes no Brasil. Revista USP, vol. 30, p. 190-238.

WINEMILLER, KO., 1996. Dynamic diversity in fish assemblages of tropical rivers. In CODY, ML. and SMALLWOOD, JA. (Eds.). Long-Term Studies of Vertebrate Communities. Orlando: Academic Press. p. 99-134.

ZAR, JH., 1999. Biostatistical Analysis. 4th ed. Upper Saddle River: Prentice-Hall. 663 p. 